\title{
The discovery of $\mathrm{N}-1$ substituted 2-aminobenzimidazoles as zinc-dependent $S$. aureus biofilm inhibitors
}

\author{
Erick A. Lindseya ${ }^{\mathrm{a}}$, Christopher M. Brackett ${ }^{\mathrm{a}}$, Trey Mullikin ${ }^{\mathrm{a}}$, Cristina Alcaraz ${ }^{\mathrm{a}}$, and Christian \\ Melandera \\ Christian Melander: ccmeland@ncsu.edu \\ aDepartment of Chemistry, North Carolina State University, Raleigh, NC 27695-8204, USA. Fax: \\ (+1)919-515-5079; Tel: (+1)919-513-2960
}

\section{Abstract}

A diverse 23-compound library of N-1 substituted 2-aminobenzimidazoles was synthesized via an efficient three-step process. This small library produced several non-toxic biofilm modulators of two strains of MRSA. Preliminary mechanistic studies reveal a zinc-dependent mode of action for these compounds.

\begin{abstract}
Drug resistance is quickly becoming one of the greatest threats to mankind. Of particular concern is the selection and evolution of pathogenic bacterial species that are resitant to many, if not all clinically available antibiotics. These bacterial species typically strike hospitalized patients and others who are immunocompromised. For example, methicillin resistant Staphylococcus aureus (MRSA) is responsible for $60-80 \%$ of $S$. aureus infections found in hospitals. ${ }^{1}$ In the United States, the number of deaths attributed to MRSA infections greatly outweighs those caused by HIV/AIDS. ${ }^{2}$ Bacteria have developed a number of strategies to protect themselves from antibiotic threats. One of these antibiotic resistant phenotypes is termed a biofilm, which is typically defined as a surface accreted community of microorganisms enveloped in an extracellular matrix. ${ }^{3}$ In this defensive state, bacteria exhibit slowed metabolism and display up to 1000 -fold enhanced resistance to antibiotic treatment. ${ }^{4}$ Bacterial biofilms are thought to be responsible for over $80 \%$ of infections found in the human body. ${ }^{5}$ Biofilm mediated infections are especially problematic within dental disease ${ }^{6}$, urinary tract infections, ${ }^{7}$ infections of indwelling medical devices, and persistent lung infections experienced by cystic fibrosis patients. ${ }^{8}$ It is therefore of upmost importance to modulate bacterial virulence, such as biofilm formation.

A strategy that is frequently employed when designing novel biofilm modulators is the directed analogue synthesis of natural product inspired motifs. ${ }^{9}$ The bromoageliferin (1) inspired 2-aminoimidazoles (2) have shown great success as modulators of both Grampositive and Gram-negative biofilms. ${ }^{10-18}$ The biofilm modulating capability of the structurally analogous 2-aminobenzimiadole (2-ABI, 3) has however remained significantly under explored in comparison. (Figure 1). Our group established that certain 2-ABIs are capable of inhibiting and dispersing Gram-positive biofilms via a zinc-dependent mechanism, ${ }^{19}$ while more recent studies from the Blackwell group ${ }^{20}$ has shown that properly designed 2-ABIs are capable of both inhibiting and dispersing Pseudomonas
\end{abstract}

\footnotetext{
Correspondence to: Christian Melander, ccmelandencsu . edu.

$\dagger$ Electronic Supplementary Information (ESI) available: [details of any supplementary information available should be included here]. See DOI: 10.1039/b000000x/

‡Footnotes should appear here. These might include comments relevant to but not central to the matter under discussion, limited experimental and spectral data, and crystallographic data.
} 
aeruginosa biofilms. The 2-ABIs have also exhibited antibiotic properties against both Gram-positive and Gram-negative bacteria. ${ }^{21}$

Our group has recently shown that 1,5-substituted 2-aminoimidazoles display enhanced biological activities as compared to their monosubstituted counterparts. ${ }^{22}$ With this in mind, we set out to improve both the antibiotic efficacy as well as the biofilm modulating capability of the 2-ABIs through the utilization of N-1 substitution. Due to its broadspectrum activity, compound $\mathbf{3}$ was selected as the parent structure for this library. The synthesis began with the acylation of commercially available 4-fluoro-3-ntiroaniline with 4pentylbenzoyl chloride, providing 4 in excellent yield. (Scheme 1). The introduction of N-1 substituents was accomplished by nucleophilic aromatic substitution of $\mathbf{4}$ with various amines, followed by reduction of the subsequent nitro-compounds under transfer hydrogenation conditions. Condensation with cyanogen bromide provided the N-1 substituted 2-ABIs, 5-26 in an efficient three-step process.

Each 2-ABI was initially investigated for their antibacterial properties, using the minimum inhibitory concentration (MIC) assay (Table 1) under standard CLSI conditions. Substitution at the N-1 position of the parent 2-ABI (3) adversely affects the ability of 5-26 to act on the Gram-negative Acinetobacter baumannii BAA-1605 and $P$. aeruginosa PA14, with only 5 and $\mathbf{6}$ showing any antibiotic behavior. Against the Gram-positive $S$. aureus, however, 5-26 most displayed antibacterial properties. Against the nine $S$. aureus strains examined (8 MRSA, 1 MSSA) the antibacterial activity of the 2-ABIs $\mathbf{6}-\mathbf{1 0}$ generally decreased with increasing chain length. The 2-ABI 7 was shown to be the most potent antimicrobial agent with MIC values of $8 \mu \mathrm{g} / \mathrm{mL}$ against all nine $S$. aureus strains, while $\mathbf{1 0}$ was shown to be inactive at the highest concentration tested $(64 \mu \mathrm{g} / \mathrm{mL})$ against the staphylococcal strains. Compound 11 returned MIC values of $8-16 \mu \mathrm{g} / \mathrm{mL}$ indicating that cyclic side chains are well tolerated. Both the aniline and benzyl derivatives (12-13) were inactive, however 15 was shown to be an effective anti-microbial, returning MIC values of $8-16 \mu \mathrm{g} / \mathrm{mL}$. Compounds 16, 17, 18 and 22 also returned MIC values of $8-16 \mu \mathrm{g} / \mathrm{mL}$ against the various $S$. aureus strains. Both $\mathbf{2 0}$ and $\mathbf{2 3}$ were shown to be non-microbicidal at the highest concentration tested $(64 \mu \mathrm{g} / \mathrm{mL})$. An increase in the number of methylene units between the 2-ABI warhead and aromatic substituent proved deleterious to the antibiotic behavior of 2426, which returned MIC values of $16-64 \mu \mathrm{g} / \mathrm{mL}$.

Given the biological activity shown by the $\mathrm{N}-1$ substituted 2-ABIs, we elected to investigate their ability to inhibit biofilm formation of MRSA strains 43300 and BAA-44 (Table 2). The parent 3 returned an $\mathrm{IC}_{50}$ value (concentration at which $50 \%$ of the biofilm is inhibited) of $13.9 \mu \mathrm{M}$ against 43300 , and was ineffective against BAA- 44 at the highest concentration tested $(20 \mu \mathrm{M})$. Compounds $\mathbf{5}, \mathbf{1 0}, \mathbf{1 2}$ and $\mathbf{2 0}$ were unable to inhibit biofilm formation against either MRSA strain. Alkyl derivatives 6-9, and $\mathbf{1 1}$ returned $\mathrm{IC}_{50}$ values ranging from 3.6 $-9.3 \mu \mathrm{M}$ against 43300 , and $4.3-9.4 \mu \mathrm{M}$ against BAA-44. The phenyl substituted 2-ABIs, 13, 15, 24 and 25 gave $\mathrm{IC}_{50}$ values ranging from $4.7-6.9 \mu \mathrm{M}$, and $5.2-14.3 \mu \mathrm{M}$ against 43300 and BAA-44 respectively. The introduction of methoxy substituents on the phenyl ring was well tolerated providing $\mathrm{IC}_{50}$ values for $14,16,17$, and 18 that were similar to the corresponding phenyl derivatives against both 43300 and BAA-44. The N-1 substituted 2-ABIs retained their anti-biofilm properties when substituted with various heterocycles. The indole derivative $\mathbf{2 2}$ was the most potent of these 2-ABIs with $\mathrm{IC}_{50}$ values of 3.7 and $4.4 \mu \mathrm{M}$ for 43300 and BAA-44 respectively. Compound 21 was also effective against both 43300 and BAA-44, returning $\mathrm{IC}_{50}$ values of 7.2 and $8.9 \mu \mathrm{M} ; \mathbf{2 3}$ was effective against only 43300 producing an $\mathrm{IC}_{50}$ of $7.0 \mu \mathrm{M}$.

We next examined the ability of the $\mathrm{N}-1$ substituted 2-ABIs to disperse preformed biofilms of 43300. Unfortunately none of the compounds were effective dispersal agents at the 
highest concentration tested $(20 \mu \mathrm{M})$. Growth curves were then constructed at the $\mathrm{IC}_{50}$ concentrations to assess the viability of planktonic cell growth. Growth curve analysis against 43300 exposed that $\mathbf{3}, \mathbf{1 7}$ and $\mathbf{2 2}$ elicit their activity via a toxic mechanism.

Compounds 18, 19, 25 and 26 were shown to retard bacterial growth between 6 and 8 hours, however they display identical cell densities at 2, 4, and 24 hours. The remaining compounds did not affect planktonic growth at their $\mathrm{IC}_{50}$ concentrations. Growth curve analysis revealed 16, 18, 19, 22, and 25 were toxic to BAA-44 planktonic cell growth. Both 14 and 26 also affected bacterial growth, in the same manner described above, against BAA-44. The remaining compounds were shown to act via a non-microbicidal mechanism.

It is known that metal ion homeostasis is crucial for bacterial biofilm development. ${ }^{23-29} \mathrm{We}$ sought to explore the role of divalent cations, specifically $\mathrm{Ca}, \mathrm{Cu}, \mathrm{Fe}, \mathrm{Mg}, \mathrm{Mn}$, and $\mathrm{Zn}$, in biofilm formation of 43300 . Biofilm formation was unaffected by $\mathrm{CaCl}_{2}, \mathrm{CuCl}_{2}, \mathrm{FeSO}_{4}$, $\mathrm{MgCl}_{2}, \mathrm{MnCl}_{2}$ and $\mathrm{ZnCl}_{2}$ at the highest concentration tested $(500 \mu \mathrm{M})$. To examine the ability of the cations to modulate the inhibitory effects of our two lead compounds, $\mathbf{8}$ and $\mathbf{1 5}$, a dose dependent study was performed under varying cation concentration, while keeping the concentration of both $\mathbf{8}$ and $\mathbf{1 5}$ constant at $8 \mu \mathrm{M}$. As seen in Figure 2, the ability of $\mathbf{8}$ and 15 to inhibit bacterial biofilm formation was unaffected by $\mathrm{Ca}, \mathrm{Cu}, \mathrm{Fe}, \mathrm{Mg}$, and $\mathrm{Mn}$ ions. The ability of $\mathbf{8}$ and $\mathbf{1 5}$ to inhibit biofilm formation by 43300 was selectively obstructed by the presence of $\mathrm{ZnCl}_{2}$. 2-ABI 15 is an effective anti-biofilm agent in low $\mathrm{Zn}$ (II) concentrations (i.e. $<50 \mu \mathrm{M}$ ), inhibiting approximately $70 \%$ of biofilm formation at $8 \mu \mathrm{M}$. When in a Zn (II) rich environment (i.e. > $50 \mu \mathrm{M}$ ) the ability of $\mathbf{1 5}$ to inhibit biofilm formation drops precipitously, with only $\sim 10 \%$ inhibition of biofilm formation in the presence of $200 \mu \mathrm{M} \mathrm{Zn}$ (II). This indicates that the mechanism by which the N-1 substituted 2-ABIs are acting is both selectively and deleteriously affected by high concentrations of $\mathrm{Zn}$ (II).

\section{Conclusions}

In conclusion we have synthesized a diverse class of $23 \mathrm{~N}-1$ substituted 2-ABIs in an efficient three step process. The N-1 substitution of $\mathbf{3}$ proved advantageous, yielding 16 nontoxic biofilm inhibitors of 43300 with $\mathrm{IC}_{50}$ values less than $10 \mu \mathrm{M}$ and 12 non-toxic biofilm inhibitors of BAA-44 with $\mathrm{IC}_{50}$ values less than $12 \mu \mathrm{M}$. We have also shown that the mode of action of the N-1 substituted 2-ABI class of compounds is selectively inhibited by high concentrations of $\mathrm{Zn}$ (II).

\section{Supplementary Material}

Refer to Web version on PubMed Central for supplementary material.

\section{Acknowledgments}

The authors would like to thank the National Institutes of Health (GM055769) as well as Glaxo Smith Kline (predoctoral fellowship to EL) for support of this work

\section{Notes and references}

1. Taubes G. Science. 2008; 321:356-361. [PubMed: 18635788]

2. Bancroft EA. Jama. 2007; 298:1803-1804. [PubMed: 17940239]

3. Donlan RM, Costerton JW. Clin Microbiol Rev. 2002; 15:167-193. [PubMed: 11932229]

4. Rasmussen TB, Givskov M. Int J Med Microbiol. 2006; 296:149-161. [PubMed: 16503194]

5. Singh PK, Schaefer AL, Parsek MR, Moninger TO, Welsh MJ, Greenberg EP. Nature. 2000; 407:762-764. [PubMed: 11048725] 
6. Soysa NS, Samaranayake LP, Ellepola AN. Oral Dis. 2008; 14:138-143. [PubMed: 18302673]

7. Richards JJ, Melander C. Chembiochem. 2009; 10:2287-2294. [PubMed: 19681090]

8. Stewart PS, Costerton JW. Lancet. 2001; 358:135-138. [PubMed: 11463434]

9. Huigens RW 3rd, Richards JJ, Parise G, Ballard TE, Zeng W, Deora R, Melander C. J Am Chem Soc. 2007; 129:6966-6967. [PubMed: 17500516]

10. Ballard TE, Richards JJ, Aquino A, Reed CS, Melander C. J Org Chem. 2009; 74:1755-1758. [PubMed: 19132935]

11. Huigens RW 3rd, Ma L, Gambino C, Moeller PD, Basso A, Cavanagh J, Wozniak DJ, Melander C. Mol Biosyst. 2008; 4:614-621. [PubMed: 18493660]

12. Reed CS, Huigens RW 3rd, Rogers SA, Melander C. Bioorg Med Chem Lett. 20:6310-6312. [PubMed: 20846860]

13. Reyes S, Huigens RW 3rd, Su Z, Simon ML, Melander C. Org Biomol Chem. 9:3041-3049. [PubMed: 21394327]

14. Richards JJ, Ballard TE, Huigens RW 3rd, Melander C. Chembiochem. 2008; 9:1267-1279. [PubMed: 18431726]

15. Richards JJ, Huigens RW III, Ballard TE, Basso A, Cavanagh J, Melander C. Chem Commun (Camb). 2008:1698-1700. [PubMed: 18368169]

16. Richards JJ, Reed CS, Melander C. Bioorg Med Chem Lett. 2008; 18:4325-4327. [PubMed: 18625555]

17. Rogers SA, Bero JD, Melander C. Chembiochem. 11:396-410. [PubMed: 20049758]

18. Su Z, Peng L, Worthington RJ, Melander C. ChemMedChem. 6:2243-2251. [PubMed: 21928438]

19. Rogers SA, Huigens RW 3rd, Melander C. J Am Chem Soc. 2009; 131:9868-9869. [PubMed: 19621946]

20. Frei R, Breitbach AS, Blackwell HE. Angew Chem Int Ed Engl. 51:5226-5229. [PubMed: 22488868]

21. Huigens RW 3rd, Reyes S, Reed CS, Bunders C, Rogers SA, Steinhauer AT, Melander C. Bioorg Med Chem. 18:663-674. [PubMed: 20044260]

22. Harris TL, Worthington RJ, Melander C. Bioorg Med Chem Lett. 2011; 21:4516-4519. [PubMed: 21737267]

23. Arrizubieta MJ, Toledo-Arana A, Amorena B, Penades JR, Lasa I. Journal of bacteriology. 2004; 186:7490-7498. [PubMed: 15516560]

24. Baker J, Sitthisak S, Sengupta M, Johnson M, Jayaswal RK, Morrissey JA. Applied and environmental microbiology. 2010; 76:150-160. [PubMed: 19880638]

25. Banin E, Brady KM, Greenberg EP. Applied and environmental microbiology. 2006; 72:20642069. [PubMed: 16517655]

26. Conrady DG, Brescia CC, Horii K, Weiss AA, Hassett DJ, Herr AB. Proceedings of the National Academy of Sciences of the United States of America. 2008; 105:19456-19461. [PubMed: 19047636]

27. Deighton M, Borland R. Infection and immunity. 1993; 61:4473-4479. [PubMed: 8406839]

28. Musk DJ, Banko DA, Hergenrother PJ. Chemistry \& biology. 2005; 12:789-796. [PubMed: 16039526]

29. Musk DJ Jr, Hergenrother PJ. Journal of applied microbiology. 2008; 105:380-388. [PubMed: 18284482] 
<smiles>Nc1nc([C@H]2c3nc(N)[nH]c3C[C@H](CNC(=O)c3cc(Br)c[nH]3)[C@H]2CNC(=O)c2cc(Br)c(Br)[nH]2)c[nH]1</smiles><smiles>[R]c1nc(N)n([R1])c1[R]</smiles>

2<smiles>CCCCCc1ccc(C(=O)Nc2ccc3[nH]c(N)nc3c2)cc1</smiles>

Figure 1.

Various anti-biofilm agents based on bromoageliferin 

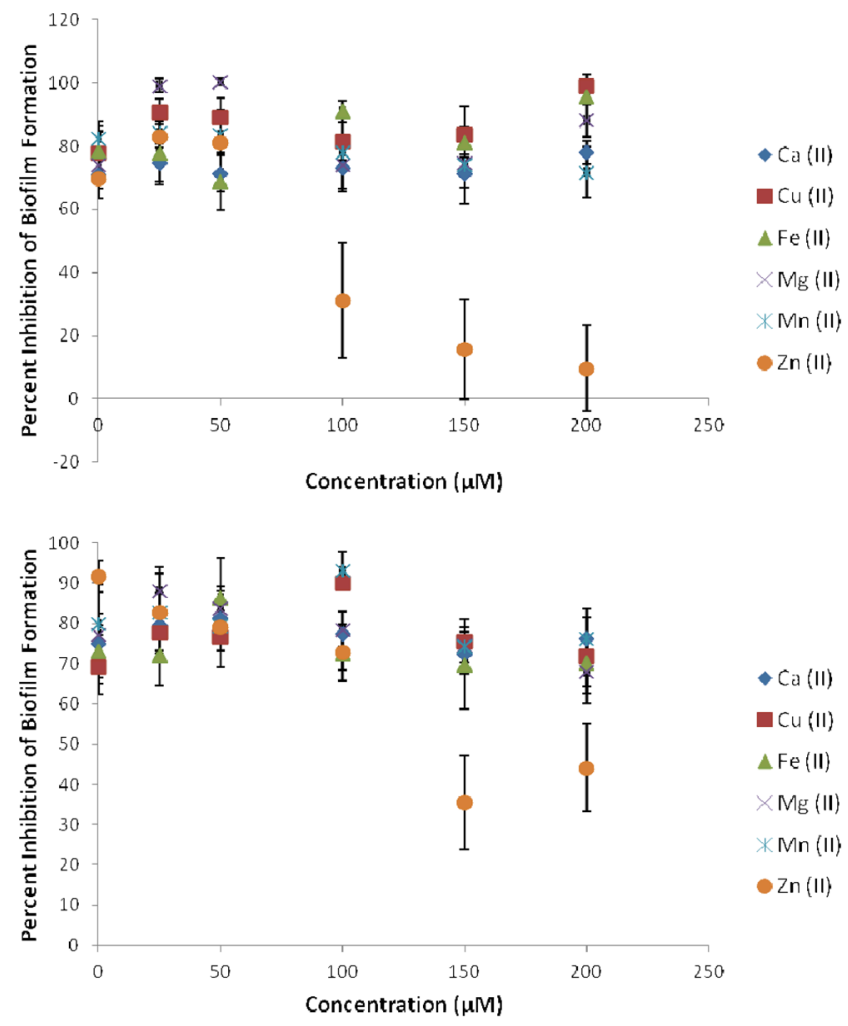

Figure 2.

Mitigating effects of divalent cations on $\mathbf{8}$ (top) and $\mathbf{1 5}$ (bottom) 
<smiles>Nc1ccc(F)c([N+](=O)[O-])c1</smiles><smiles>CC(C)Cc1ccc(C(=O)Cl)cc1</smiles><smiles>CC(C)c1ccc(C(=O)Nc2ccc(F)c([N+](=O)[O-])c2)cc1</smiles>

4<smiles>[R]n1c(N)nc2cc(NC(=O)c3ccc(C(C)C)cc3)ccc21</smiles>

R:<smiles>C[15CH3]</smiles>

1. $\mathrm{RNH}_{2}, \mathrm{EtOH}$

4

2. $\mathrm{NH}_{4} \mathrm{HCO}_{2}, \mathrm{Pd} / \mathrm{C}, \mathrm{EtOH}$

3. $\mathrm{BrCN}, \mathrm{EtOH} / \mathrm{CHCl}_{3}$

4. $\mathrm{MeOH} / \mathrm{HCl}$

$Y^{z_{i}} 6$

$y_{3}^{2}$
3

$x y_{5}^{2}{ }^{2} 8$

$Y_{7}^{2} r^{2}=9$

$+1+x_{2}^{2}$

15

13<smiles>[14CH3]Cc1ccccc1</smiles>

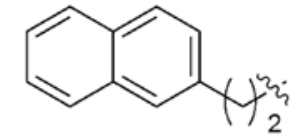
19<smiles>CCc1ccc(OC)cc1</smiles>

$X y_{11}^{2}$<smiles>[TeH]C1CCCC1</smiles><smiles>Nc1cccc2ccccc12</smiles>

20

21<smiles>[Y16]c1nc2ccccc2[nH]1</smiles><smiles>CC(C)(C)c1c[nH]c2ccccc12</smiles>
26

Scheme 1.

Synthetic outline of N-1-substituted 2-ABIs 


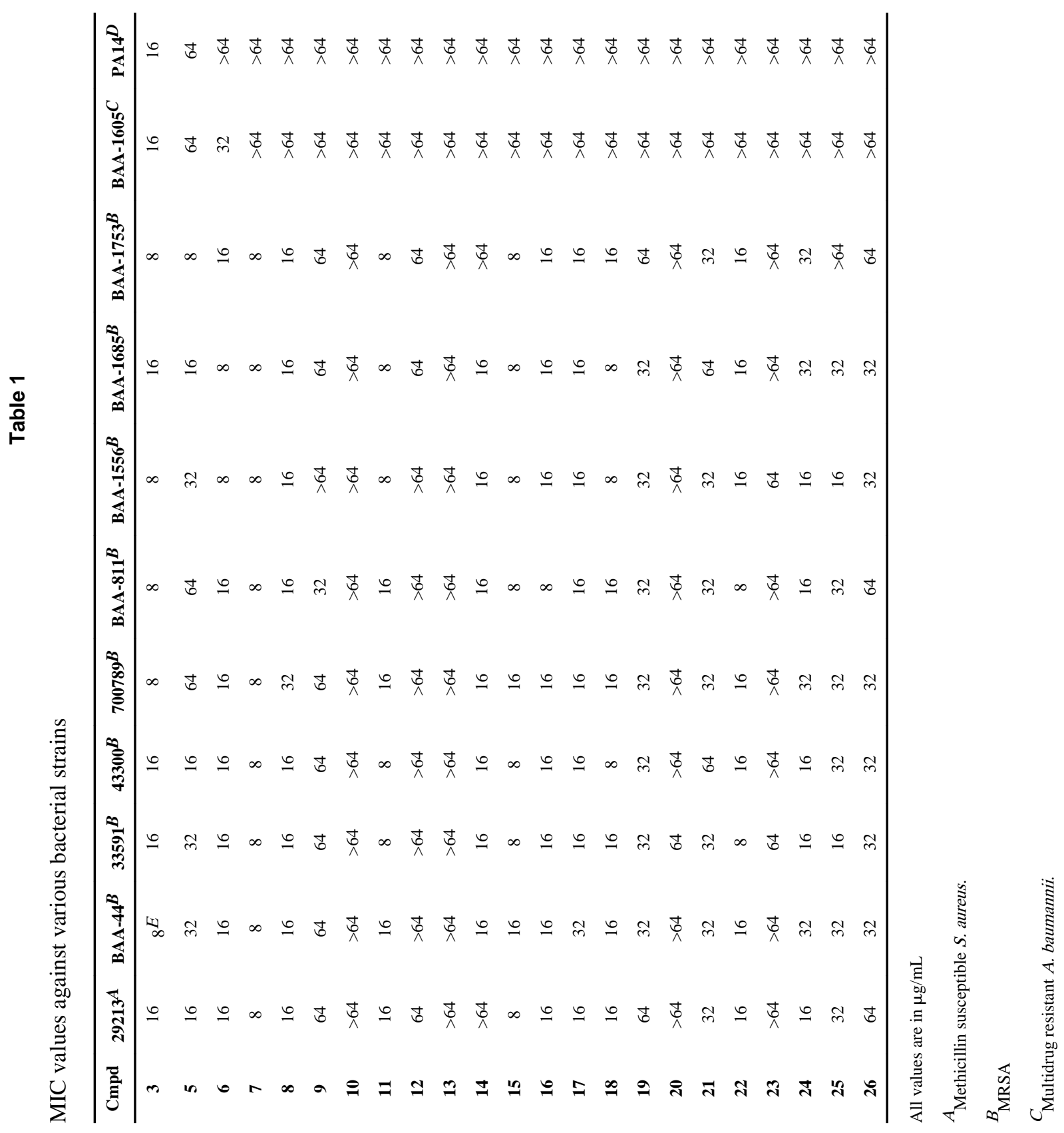

Medchemcomm. Author manuscript; available in PMC 2013 January 01. 


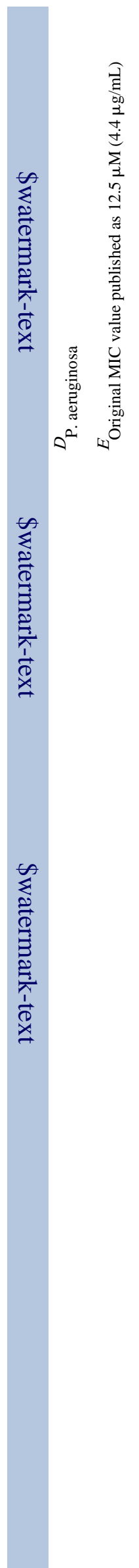

Medchemcomm. Author manuscript; available in PMC 2013 January 01. 
Table 2

Biofilm inhibition $\left(\mathrm{IC}_{50}\right.$ values) against two MRSA strains

\begin{tabular}{ccc}
\hline Cmpd & $\mathbf{4 3 3 0 0}$ & BAA-44 \\
\hline $\mathbf{3}$ & $13.9 \pm 1.0$ & $>20$ \\
$\mathbf{5}$ & $>20$ & $>20$ \\
$\mathbf{6}$ & $7.9 \pm 2.0$ & $9.4 \pm 2.4$ \\
$\mathbf{7}$ & $4.5 \pm 0.5$ & $5.0 \pm 1.3$ \\
$\mathbf{8}$ & $4.7 \pm 0.8$ & $7.3 \pm 1.5$ \\
$\mathbf{9}$ & $9.3 \pm 2.2$ & $6.8 \pm 1.8$ \\
$\mathbf{1 0}$ & $>20$ & $>20$ \\
$\mathbf{1 1}$ & $3.6 \pm 0.8$ & $4.3 \pm 0.9$ \\
$\mathbf{1 2}$ & $>20$ & $>20$ \\
$\mathbf{1 3}$ & $5.2 \pm 2.1$ & $6.8 \pm 2.5$ \\
$\mathbf{1 4}$ & $5.7 \pm 1.7$ & $11.5 \pm 4.2$ \\
$\mathbf{1 5}$ & $4.7 \pm 0.6$ & $6.0 \pm 1.6$ \\
$\mathbf{1 6}$ & $5.7 \pm 1.4$ & $7.3 \pm 2.6$ \\
$\mathbf{1 7}$ & $6.1 \pm 1.4$ & $9.3 \pm 2.2$ \\
$\mathbf{1 8}$ & $6.2 \pm 0.5$ & $10.4 \pm 1.3$ \\
$\mathbf{1 9}$ & $5.7 \pm 1.4$ & $14.3 \pm 4.3$ \\
$\mathbf{2 0}$ & $>20$ & $>20$ \\
$\mathbf{2 1}$ & $7.2 \pm 1.5$ & $8.9 \mathrm{v} 1.4$ \\
$\mathbf{2 2}$ & $3.7 \pm 0.5$ & $4.4 \pm 1.0$ \\
$\mathbf{2 3}$ & $7.0 \pm 1.9$ & $>20$ \\
$\mathbf{2 4}$ & $4.7 \pm 0.7$ & $5.2 \pm 2.1$ \\
$\mathbf{2 5}$ & $6.9 \pm 1.1$ & $14.3 \pm 1.7$ \\
$\mathbf{2 6}$ & $5.7 \pm 1.5$ & $7.9 \pm 1.9$ \\
\hline & &
\end{tabular}

All values are in $\mu \mathrm{M}$ 